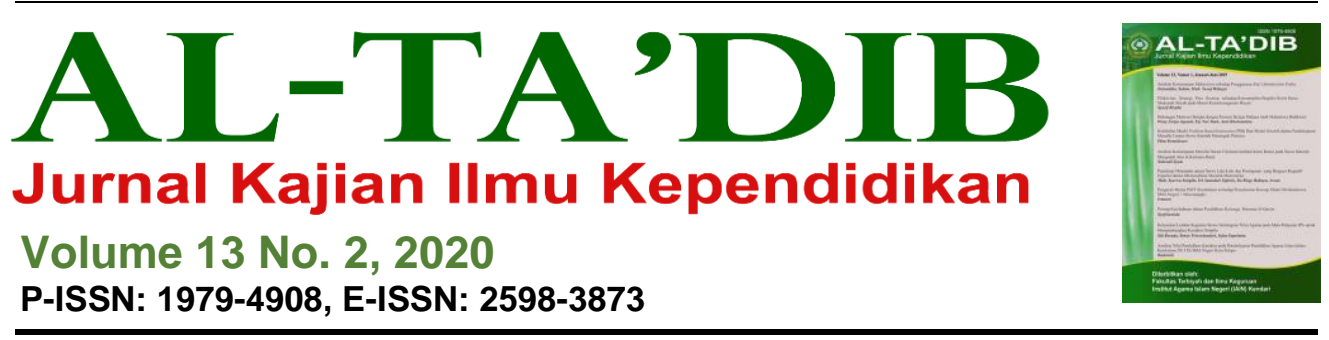

\title{
Integrasi Program Tahfidz dengan Sekolah Formal di Pondok Pesantren Anak
}

\section{Ngabdul Faqih ${ }^{1}$}

${ }^{1}$ Institut Agama Islam Negeri (IAIN) Salatiga, Indonesia. E-mail: ngabdul03@gmail.com

\section{ARTICLE INFO}

Keywords:

Children Islamic boarding school; Islamic elementary school; formal school; integration; tahfidz

\section{How to Cite:}

Faqih, N. (2020).

Integrasi program tahfidz dengan sekolah formal di pondok pesantren anak. Al-Ta'dib: Jurnal Kajian Ilmu Kependidikan, 13(2), 92-102.

\begin{abstract}
This article aims to present the analysis of the integration of the tahfidz program with formal schools in the Islamic boarding schools focusing on the Holy Qur'an memorization in East Java, Indonesia. This phenomenology study used data gathered from interviews, observation and documentation. The results of data analysis indicate that the model of the integration of the tahfidz program from Islamic boarding schools into the madrasah ibtida'iyyah (MI) curriculum is done by adding Qur'an Hadith subject with the allocation of two lesson hours per week requiring students to memorize the Qur'an in accordance with the target to support the tahfidz program in Islamic boarding schools. It is also found that the advantage of the tahfidz program integration model is to accelerate students' ability to memorize because of the similarity of the tahfidz method used as well as the presence of additional subjects in the curriculum that support the tahfidz program.
\end{abstract}


INFORMASI ARTIKEL

Kata Kunci:

Integrasi; pondok pesantren anak; madrasah ibtida'iyyah; sekolah formal; tahfidz

\section{Cara Mensitasi:}

Faqih, N. (2020).

Integrasi program tahfidz dengan sekolah formal di pondok pesantren anak. Al-Ta'dib: Jurnal Kajian Ilmu Kependidikan, 13(2), 92-102.

\begin{abstract}
ABSTRAK
Artikel ini bertujuan untuk menyajikan analisis integrasi program tahfidz dengan sekolah formal di pondok pesantren anak di Jawa Tengah, Indonesia. Penelitian fenomenologi ini mengumpulkan data dari hasil wawancara, observasi dan dokumentasi. Temuan penelitian menunjukkan bahwa model integrasi program tahfidz dari pondok pesantren ke dalam kurikulum madrasah ibtida'iyyah (MI) dilakukan dengan cara menambahkan mata pelajaran Qur'an Hadis dengan alokasi dua jam pelajaran tiap minggu. Dalam pelaksanaannya, program ini juga mengharuskan siswa menghafal al-Qur'an sesuai dengan target untuk mendukung program tahfidz di pondok pesantren. Keunggulan model integrasi program tahfidz yaitu mempercepat kemampuan siswa dalam menghafal karena adanya kesamaan metode tahfidz yang digunakan serta adanya mata pelajaran tambahan dalam kurikulum yang mendukung program tahfidz.
\end{abstract}

\section{Pendahuluan}

Menghafal Al-Qur'an merupakan keistimewaan dan kelebihan buat seorang Muslim karena tidak semua mampu untuk melakukan tahfidz. Al-Qur'an dapat dihafal oleh orang-orang yang tidak bisa membaca dan menulis karena mereka menggunakan daya ingat dan pendengaran untuk melakukan tahfidz. Demikian pula dengan orang-orang yang memiliki kekurangan secara fisik seperti tidak bisa melihat (buta) juga mampu menghafal dengan sempurna, bahkan kadang hafalan mereka lebih kuat dari pada orang-orang yang mempunyai penglihatan yang normal (Sistupani, 2017). Al-Qur'an juga mampu dihafal oleh semua tingkat usia, tua maupun muda. Anak-anak di usia sangat belia seperti usia di bawah tujuh tahun dapat menghafal alQur'an (Wahyuni \& Syahid, 2019).

Masa usia dini merupakan periode emas (golden age) bagi perkembangan anak untuk terlibat dalam proses belajar, termasuk menghafal al-Qur'an. Kegiatan menghafal al-Qur'an akan lebih mudah dihafal dan direkam oleh anak-anak sejak usia dini (Apriati, 2020). Hal ini perlu dilakukan sejak dini mengingat dampak globalisasi yang turut mempengaruhi perilaku anak yang membuat mereka lupa kewajiban mereka sebagai pelajar yang seharusnya mampu berprestasi dan senantiasa membudidayakan membaca, termasuk membaca al-Qur'an bagi muslim (Rohman, 2016; Sistupani, 2017). Kebutuhan akan program menghafal Al- 
Qur'an bagi anak-anak usia dini semakin meningkat. Didirikannya lembagalembaga tahfidz yang memiliki program khusus menghafal al-Qu'ran untuk anak usia sekolah dasar merupakan bukti atas kebutuhan tersebut (Wahyuni \& Syahid, 2019). Program tahfidz untuk anak usia SD yang diselenggarakan oleh lembaga pondok pesantren juga selalu membekali anak-anak dengan pendidikan formal di jenjang sekolah dasar (SD) atau madrasah ibtidaiyah (MI).

Pondok pesantren terintegrasi dengan lembaga pendidikan modern termasuk dalam pondok pesantren modern (modern boarding school). Madrasah adalah salah satu contoh sistem pendidikan yang terintegrasi penuh ke dalam sistem tradisional dan sistem sekolah formal (Purwati, Zubaidah, Corebima, \& Mahanal, 2018). Tujuan dari proses moderasi sekolah asrama adalah untuk mencoba menyempurnakan sistem pendidikan Islam yang ada saat ini (Yuli, Haningsih, \& Adikrishna, 2011). Di Indonesia, madrasah menerapkan kurikulum madrasah yang terdiri atas $70 \%$ mata pelajaran umum dan 30\% pelajaran agama (Purwati, dkk., 2018). Sementara itu, MI termasuk pendidikan formal yang pelaksanaannya dikelola oleh kementerian agama, tetapi kurikulumnya terintegrasi dengan kurikulum pendidikan nasional (Ma'zumi \& Jakaria, 2012). Embong, Rahman, Ibrahim, Abdullah, Adam, Omar, Wahid, \& Omar (2017) menegaskan bahwa integrasi dapat dimaknai sebagai bagian dari interpretasi al-Qur'an atas penemuan ilmiah dan modern. Dalam tataran pembelajaran, integrasi meliputi hal yang kompleks, yang melibatkan kurikulum, pengajaran, guru, sarana prasarana, manajemen, dan evaluasi yang komprehensif sehingga tercipta sekolah berbasis integrasi yang efektif dan berkualitas (Hidayah, 2016; Piliang, Daulay, \& Siddik, 2017). Terkait integrasi program tahfidz dengan sekolah formal, ada berbagai faktor pendukung program tahfidzul Qur'an pada lembaga pendidikan formal, yaitu: usia, siswa muda, asrama yang nyaman dan mentor yang memantau kegiatan sehari-hari siswa. Akan tetapi, program ini juga memiliki potensi penghambat, yaitu: minimnya kemampuan siswa dalam membaca al-Qur'an, kurangnya budaya membaca al-Qur'an, banyaknya beban kegiatan siswa sehingga mereka tidak hanya fokus pada program tahfidzul Qur'an tetapi juga pada kegiatan lainnya (Rohman, 2016).

Berbagai penelitian terkait program tahfidz al-Qur'an telah dilakukan secara empiris baik di skala global maupun nasional (Badruzaman, 2019; Bahruddin, Mujahidin, \& Hafidhuddin, 2017; Chotimah, Rifai, \& Prihatin, 2018; Embong et al., 2017; Goensch, 2016; Rahmi, 2019; Rikardo, 2020). Penelitian Goensch (2016) melaporkan bahwa anak-anak kecil dan anak lakilaki lebih cenderung memilih bersekolah di sekolah tahfidz, sedangkan anakanak yang lebih besar dan anak perempuan lebih memilih bersekolah di sekolah formal. Di Indonesia, penelitian Bahruddin, dkk (2017) yang fokus 
pada metode tahfidz al-Qur'an untuk anak-anak di pondok pesantren menemukan bahwa konsep tahfidz al-Qur'an metode ahsani menggabungkan pikiran, jiwa dan raga dalam melakukan tahfidz al-Qur'an sehingga bisa menjadi metode tahfidz yang baik bagi anak-anak. Sementara itu, penelitian Supian, Vahlepi, \& Sholiha (2019) menemukan bahwa salah satu faktor pendukung bangkitnya gerakan program tahfidz al-Qur'an adalah motivasi dari para guru dan orang tua. Dengan sistem kelembagaan yang modern, program yang fleksibel mampu menjangkau hampir seluruh lapisan masyarakat dengan menggunakan metode pembelajaran yang inovatif dan kreatif sesuai dengan perkembangan jaman. Serupa dengan penelitian sebelumnya, hasil penelitian Embong, dkk (2017) menunjukkan bahwa perspektif Said Nursi menekankan bahwa kebangkitan umat di seluruh dunia bisa melalui kurikulum terpadu antara ilmu agama sekuler dan tradisional modern. Ini berarti bahwa masalah dualisme pendidikan harus diselesaikan melalui integrasi dimana kedua ilmu bersifat saling melengkapi. Akan tetapi, Hidayah (2016) menegaskan bahwa para pengelola lembaga pendidikan Islam yang mengelola program tahfidz perlu memerhatikan beberapa strategi dalam manajemennya, seperti perbaikan manajemen lembaga, penyediaan lingkungan yang kondusif untuk kegiatan tahfidz, perencanaan kurikulum tahfidz yang matang, penguatan instruktur tahfidz melalui program pengembangan profesional, dan pemilihan metode dan mekanisme tahfidz yang tepat oleh instruktur.

Mespikun sudah banyak penelitian yang fokus menyelidiki tentang integrasi program tahfidz dengan sekolah formal, akan tetapi penelitian yang membahas tentang integrasi antara program tahfidz di pondok pesantren dengan dengan lembaga pendidikan formal masih kurang dieksplorasi (lihat Chotimah, dkk., 2018). Oleh karena itu, penelitian ini sangat penting dilakukan untuk memberikan gambaran bagaimana integrasi program tahfidz di pondok pesantren dan lembaga pendidikan formal, khususnya di tingkat MI. Penelitian ini fokus pada dua hal, yaitu bagaimana integrasi program tahfidz dengan sekolah formal di pondok pesantren anak dan apa saja yang menjadi keunggulan model integrasi program tahfidz dengan sekolah formal di pondok pesantren anak.

\section{Metode Penelitian}

Penelitian ini menggunakan pendekatan kualitatif fenomenologi yang berlandaskan pada filsafat postpositivisme, yang digunakan untuk meneliti pada kondisi alamiah (Thorburn \& Stolz, 2020). Penelitian fenomenologi ini dilaksanakan di Pondok Pesantren Yan'buul Qur'an. Pondok pesantren ini adalah salah satu pondok pesantren tahfidz al-Qur'an anak-anak di Kudus, Jawa Tengah. Pondok pesantren ini merupakan pondok pesantren khusus 
untuk anak-anak usia 6-12 tahun, atau setingkat SD atau MI. Madrasah Ibtida'iyyah Tahfidzul Qur'an TBS (MITQ TBS) memiliki visi dan misi yang mendukung program tahfidz bagi anak-anak pondok pesantren tahfidz Yanbu'ul Qur'an. Pendidikan utama di pondok pesantren ini adalah menghafal al-Qur'an 30 juz. Selain menjalani program tahfidz, siswa juga belajar ilmu-ilmu agama seperti aqidah, ibadah, akhlak, tajwid dan bahasa Arab dasar. Oleh karena itu, hal ini menarik untuk diteliti lebih mendalam guna mengetahui bagaimana gambaran integrasi program tahfidz pada lembaga tersebut. Program pendidikan di pondok ini juga mengintegrasikan pendidikan formal seperti yang tersaji di Tabel 1.

Tabel 1. Jenis Pendidikan Formal di Pondok Pesantren Yanbu'ul Qur'an

\begin{tabular}{l}
\hline Pendidikan Formal \\
\hline Madrasah Tasywiquth Thullab Salafiyyah (TBS) \\
Madrasah Ibtida'iyyah Tahfidzul Qur'an TBS (MITQ TBS) \\
Madrasah Tsanawiyah (MTs) - Pesantren satu atap dengan tahfidz Yanbu'ul Qur'an \\
Program Wajib Belajar Pendidikan Dasar (Wajardikdas) Tingkat Wustho \\
Program Paket C setara SMA/MA
\end{tabular}

Penelitian ini juga meneliti integrasi program tahfidz pada pondok pesantren di kota lain, yaitu di Pondok Pesantren Anak Tahfidzul Qur'an Raudlatul Falah Pati. Pondok pesantren ini juga merupakan pondok pesantren khusus anak setingkat MI atau SD dengan kisaran usia anak didik 6-12 tahun. Pendidikan utama di pondok ini adalah menghafal al-Qur'an dengan metode khusus yang disesuaikan dengan tingkat umur dan psikologi anak dengan tujuan menciptakan generasi penghafal al-Qur'an sejak dini. Metode yang diterapkan untuk menghafal al-Qur'an adalah musafahah, resitasi, takrir, dan mudarasah. Yayasan Raudlatul Falah juga memiliki lembaga pendidikan formal tingkat sekolah dasar yaitu MI Tahfidzul Qur'an Raudlatul Falah untuk mendukung program tahfidz pada Pondok Pesantren Anak Tahfidzul Qur'an Raudlatul Falah.

Dalam penelitian ini, peneliti merupakan instrumen kunci dan pengambilan data dilakukan secara purposive dan snowball. Sumber data penelitian ini berasal dari hasil wawancara dengan beberapa siswa, guru MI, dan ustadz serta hasil observasi pembelajaran menghafal al-Qur'an di pondok pesantren dan di MI. Penelitian ini akan menggunakan teknik wawancara semi terstruktur. Peneliti membuat pedoman wawancara secara garis besarnya saja sehingga pertanyaan dapat meluas dan mendalam pada saat proses wawancara berlangsung. Data yang terkumpul lalu dianalisis secara deskriptif melalui tiga prosedur analisis data, yaitu: reduksi data, penyajian data, dan verifikasi (Miles, Huberman, \& Saldana, 2014). Data dikoding dan dikategorisasi berdasarkan parameter integrasi program yang 
terjadi pada kedua pondok pesantren tersebut (Embong, dkk., 2017; Goensch, 2016).

\section{Temuan dan Pembahasan}

\subsection{Integrasi Program Tahfidz dengan Sekolah Formal di Pondok Pesantren Anak}

Pondok pesantren Yan'buul Qur'an Kudus menerapkan metode tahfidz ahsani dalam program menghafal al-Qur'an dengan target hafalan sebagai landasan dalam pelaksanaan tahfidz. Metode ahsani dilakukan dengan cara membagi jumlah juz dalam al-Qur'an dalam waktu yang telah ditentukan (Bahruddin, dkk., 2017). Pada program tahfidz selama enam tahun, misalnya, program dibuat menjadi sebelas semester. Hal ini dilakukan agar semester akhir menjadi waktu target untuk pengulangan terhadap hafalan 30 juz secara sempurna. Sementara itu, kegiatan pendidikan formal yang diselenggarakan oleh Pondok Tahfidz Yanbu'ul Qur'an anak hanya satu jenjang, yaitu jenjang MI kelas I hingga kelas VI dengan mengikuti kurikulum Kementerian Agama ditambah dengan materi pelajaran lokal.

Berdasarkan hasil wawancara dengan asatidz al-Qur'an di Pondok Tahfidz Yanbu'ul Qur'an, diperoleh informasi bahwa program tahfidz Qur'an menjadi satu kesatuan dengan tahfidz Qur'an di MTQ TBS. Dalam mencapai target-target hafalan Qur'an, program MI mengikuti program pondok pesantren. MI menyamakan visi dan misi sekolah dengan pondok pesantren serta mendukung program tahfidz karena MI adalah sekolah formal bagi anak-anak Pondok Pesantren Tahfidz Yanbu'ul Qur'an dengan "Hafidh dan Berakhlaq Qur'ani serta Terdepan dalam Prestasi" serta misi tercapainya anak usia 6-12 tahun yang hafidz al-Qur'an 30 juz bil ghaib. Berdasarkan hasil penelitian dapat diketahui bahwa integrasi program tahfidz dengan MI di pondok ini dilakukan dengan cara memasukkan mata pelajaran tahfidz unggulan dalam kurikulum di MI dengan alokasi waktu pembelajaran 48 jam di kelas satu hingga kelas enam sedangkan dalam jam pembelajaran di MI terdapat pembelajaran al-Qur'an hadis dengan alokasi waktu 2 jam pembelajaran setiap minggu di kelas satu hingga kelas enam. Untuk menambah kelancaran hafalan santri Khotimin Haflah diadakan acara Khotmul Qur'an (membaca al-Qur'an 30 juz bil ghoib) yang dibagi menjadi kelompok-kelompok sesuai dengan jumlah santri khotimin dalam waktu dua hari dengan disima' oleh asatidz pembimbing, wali khotimin dan santri kelas tiga sampai dengan kelas enam. Hal ini sejalan dengan yang dikatakan Hidayah (2016) terkait strategi metode dan mekanisme tahfidz.

Kualitas pendidikan al-Qur'an bagi siswa MI dari kelas satu hingga enam ditingkatkan melalui kegiatan yang dapat menunjang prestasi santri, yaitu: (1) simaan semester Qur'an yang diselenggarakan pada pada setiap 
bulan Shafar dan Ramadlan; (2) alokasi tambahan waktu khusus bagi santri calon seleksi khatmul Qur'an karantina 3 bulan; (3) kewajiban mengaji bagi santri yang khatam dan sudah mengikuti Haflah Khotmul Qur'an kepada para kiyai yang bertanggungjawab pada bidang ini. Sementara itu, guru MI pada pondok ini menggunakan strategi pembelajaran langsung dalam program tahfidz. Selain memberikan contoh cara membaca Qur'an dengan benar dan fasih, guru juga memberikan pengetahuan dasar tentang tajwid, arti dari ayat yang dibaca hingga sejarah turunnya surat Qur'an tersebut. Strategi ini pada dasarnya adalah strategi yang menempatkan guru sebagai sumber belajar, dan cukup efektif digunakan untuk menyampaikan informasi dan membentuk keterampilan secara langkah demi langkah. Strategi ini umumnya digunakan untuk memperkenalkan strategi lain pada awal pembelajaran (Hidayah, 2016).

Tabel 2. Metode Tahfidz di Pondok Pesantren Raudlotul Fallah Pati

\begin{tabular}{|c|c|}
\hline Metode & Pelaksanaan \\
\hline Musafahah & $\begin{array}{l}\text { Ustadz/ustadzah membaca, kemudian santri mendengarkan dan } \\
\text { menirukan; ustadz/ustadzah membaca kemudian santri hanya } \\
\text { mendengarkan; santri membaca kemudian ustadz/ustadzah } \\
\text { mendengarkan. }\end{array}$ \\
\hline Resitasi & $\begin{array}{l}\text { Ustadz/ustadzah memberikan tugas kepada santri untuk menghafal } \\
\text { beberapa ayat sampai hafal, kemudian santri menyetorkan hafalannya } \\
\text { kepada ustadz/ustadzah. }\end{array}$ \\
\hline Takrir & $\begin{array}{l}\text { Santri mengulang hafalannya, kemudian santri membaca hafalannya } \\
\text { di hadapan ustadz/ustadzah. }\end{array}$ \\
\hline Mudarasah & $\begin{array}{l}\text { Santri menghafal secara bergantian dan yang lain } \\
\text { mendengarkan/menyimak. }\end{array}$ \\
\hline $\begin{array}{l}\text { 1. Mudarasah } \\
\text { ayatan }\end{array}$ & $\begin{array}{l}\text { Santri membaca suatu ayat kemudian diteruskan oleh santri yang } \\
\text { lain. }\end{array}$ \\
\hline $\begin{array}{l}\text { 2. Mudarasah } \\
\text { per halaman }\end{array}$ & $\begin{array}{l}\text { Santri membaca satu halaman kemudian diteruskan oleh santri yang } \\
\text { lain. }\end{array}$ \\
\hline $\begin{array}{l}\text { 3. Mudarasah } \\
\text { per } 1 / 4 \text { juz }\end{array}$ & $\begin{array}{l}\text { Santri membaca seperempat juz kemudian diteruskan oleh santri } \\
\text { yang lain. }\end{array}$ \\
\hline Tes & $\begin{array}{l}\text { Santri menyetor hafalan kepada ustadz/ustadzah yang telah ditunjuk } \\
\text { untuk mengetahui ketetapan dan kelancaran hafalannya. }\end{array}$ \\
\hline
\end{tabular}

Pada Pondok Pesantren Anak Roudlotul Fallah Pati, integrasi program tahfidz dengan MI Tahfidzul Qur'an Raudlatul Falah juga berlaku. Berdasarkan hasil wawancara dengan ustadz sekaligus guru di MI, program tahfidz pada anak-anak di Pondok Pesantren Roudlotul Fallah Pati dilaksanakan dengan metode musafahah, resitasi, takrir, mudarasah dan tes seperti yang dipaparkan di Tabel 2. Integrasi program tahfidz di pondok 
pesantren ini dengan MI diwujudkan dalam bentuk pembelajaran al-Qur'an hadis dengan alokasi waktu dua jam pembelajam setiap minggu di kelas satu hingga kelas enam.

Program tahfidz di MI pada pondok pesantren ini dicapai dengan kompetensi dasar yang dilaksanakan secara maksimal karena kompetensi dasar tersebut menargetkan peserta didik dapat melafalkan dan menghafalkan ayat-ayat pendek serta Qur'an secara keseluruhan dengan benar dan fasih. Benar dan fasih bermakna bahwa peserta didik juga harus mengetahui tentang ilmu tajwid. Meskipun siswa kelas satu pada umumnya belum menguasai ilmu tajwid secara mendalam, namun MI sudah mulai memberikan pelajaran tajwid kepada mereka agar mereka bisa lancar dalam membaca al-Qur'an. Penelitian ini juga menemukan bahwa guru-guru di kedua MI lokasi penelitian ini telah menggunakan strategi pembelajaran interaktif. Strategi pembelajaran interaktif ini digunakan saat mereka menyajikan bahan pelajaran. Para guru menjadi pemeran utama dalam menciptakan situasi yang edukatif dan interaktif antara guru dengan siswa, siswa dengan siswa dan dengan sumber pembelajaran dalam menunjang tercapainya tujuan belajar.

\subsection{Keunggulan Model Integrasi Program Tahfidz dengan Sekolah Formal di Pondok Pesantren Anak}

Program tahfidz baik di Pondok Pesantren Yan'buul Quran Kudus maupun di Pondok Pesantren Roudlotul Fallah Pati merupakan program menghafal al-Qur'an yang wajib diikuti setiap siswa dan terintegrasi dengan kurikulum MI. Kedua MI tersebut adalah lembaga pendidikan dibawah naungan masing-masing yayasan pondok pesantren sehingga program tahfidz terintegrasi secara langsung dengan pondok pesantren. Integrasi program tahfidz dari pondok pesantren ke dalam kurikulum MI yang dilakukan dengan cara menambahkan mata pelajaran al-Qur'an hadis dengan alokasi dua jam pelajaran tiap minggu memiliki keunggulan. Pertama, alokasi dua jam pembelajaran untuk menghafal Qur'an setiap minggu sehingga membantu mempercepat siswa dalam menghafal. Kedua, MI memberikan pembelajaran lain yang mendukung program tahfidz seperti hadis, mahfudot, tahajji, lughot tajwid, fiqih, tauhid, pegon, nahwu, shorof (di MI Tahfidzul Qur'an TBS) dan pelajaran hadis, fiqih, yanbua, pegon, nahwu, tajwid, shorof, tauhid, dan tafsir di MI Tahfidzul Qur'an Raudlatul Falah. Ketiga, siswa bisa lebih cepat menghafal Qur'an karena di MI juga menerapkan metode tahfidz yang sama dengan yang diterapkan oleh ustad di pondok pesantren. Penelitian ini mengkonfirmasi temuan penelitian Bahruddin, dkk. (2017) dan Chotimah, dkk. (2018). 
Selain kurikulum yang lebih integratif, program tahfidz di Pondok Pesantren Yan'buul Quran Kudus terintegrasi dengan program tahfidz di MI Tahfidzul Qur'an TBS untuk mencapai target hafalan, yaitu: 1) kelas satu semester pertama target hafalan 1,5 juz dan semester kedua 1,5 juz sehingga minimal 3 juz dapat dihafalkan dengan baik oleh siswa kelas satu; 2) kelas dua semester pertama target 3 juz dan semester kedua 3 juz dimana siswa menghafal al-Qur'an dua setengah halaman sampai tiga halaman dalam sehari; 3) kelas tiga target hafalan 7 juz yang terbagi pada dua semester; 4) kelas empat target hafalan 6 juz di dua semester dimana hafalannya dilakukan dalam dua setengah hari sampai tiga hari dengan target satu halaman; 5) kelas lima semester pertama target 3 juz dan semester kedua target 2,5 juz sehingga target hafalan dalam tiga hari adalah satu halaman; dan 6) kelas enam semester pertama target 2,5 juz yang dapat dihafal dalam kurun waktu 3 hari dan pada semester pertama ini anak-anak sudah mendapatkan hafalan sebanyak 30 juz, sedangkan untuk semester kedua pada tahun keenam ini anak-anak hanya memiliki target muroja'ah hafalan secara keseluruhan.

\section{Kesimpulan}

Berdasarkah hasil penelitian, dapat disimpulkan bahwa Pondok Pesantren Yan'buul Quran Kudus dan Pondok Pesantren Roudlotul Falah Pati memiliki program tahfidz qur'an yang terintegrasi atau menjadi satu kesatuan dengan program tahfidz qur'an di madrasah ibtida'iyyah. Model integrasi program tahfidz dari pondok pesantren ke dalam kurikulum MI dilakukan dengan cara menambahkan mata pelajaran al-Qur'an hadis dengan alokasi dua jam pelajaran tiap minggu yang dalam pelaksanaanya juga mengharuskan siswa menghafal Qur'an sesuai dengan target untuk mendukung program tahfidz di pondok pesantren. Keunggulan model integrasi program tahfidz antara pondok pesantren dengan kurikulum MI yaitu mempercepat kemampuan siswa dalam menghafal karena adanya kesamaan metode tahfidz yang digunakan serta adanya tambahan pelajaran lain yang mendukung program tahfidz.

\section{Daftar Pustaka}

Apriati, Y. (2020). Kerjasama sekolah dan orangtua dalam proses pendidikan tahfidz Al-Qur'an pada anak di sekolah tahfidz plus SD Khoiru Ummah Banjarmasin. Padaringan: Jurnal Pendidikan Sosiologi Antropologi, 2(1), 164-173.

Badruzaman, D. (2019). Metode tahfidz Al-Qur'an di Pondok Pesantren Miftahul Huda II Kabupaten Ciamis. Idea: Jurnal Humaniora, 2(2), 245-253. 
Bahruddin, A. H., Mujahidin, E., \& Hafidhuddin, D. (2017). Metode tahfizh Al-Qur'an untuk anak-anak pada Pesantren Yanbu'ul Qur'an Kudus Jawa Tengah. Ta'dibuna: Jurnal Pendidikan Islam, 6(2), 162-172. https://doi.org/10.32832/tadibuna.v6i2.1062

Chotimah, C., Rifai, A., \& Prihatin, T. (2018). The management of the tahfidz Al Qur'an education program in children tahfidh Yanbu'ul Qur'an Islamic Boarding School Kudus. Educational Management, 7(1), 39-45.

Embong, R., Rahman, A. A. A., Ibrahim, M., Abdullah, R. T., Adam, F., Omar, S. H. S., Wahid, N. A., \& Omar, N. A. C. (2017). Integrated education as a solution for educational dualism from Said Nursi's perspective. People: International Journal of Social Sciences, 3(2), 914-928. https://doi.org/10.20319/pijss.2017.32.914928

Goensch, I. (2016). Formal school or Koranic school? Determinants of school type choice in Senegal. Oxford Development Studies, 44(2), 167-188. https://doi.org/10.1080/13600818.2015.1119262

Hidayah, N. (2016). Strategi pembelajaran tahfidz Al-Qur'an di lembaga pendidikan. Ta'allum: Jurnal Pendidikan Islam, 4(1), 63-81. https://doi.org/10.21274/taalum.2016.4.1.63-81

Ma'zumi, \& Jakaria. (2012). Contributions of madrasah to the development of the nation character. International Journal of Scientific \& Technology Research, 1(11), 37-39.

Miles, M. B., Huberman, A. M., \& Saldana, J. (2014). Qualitative data analysis (3rd ed.). New York: SAGE.

Piliang, M. Z., Daulay, H. P., \& Siddik, D. (2017). An analysis of integrated Islamic school Al Ulum in Medan, Indonesia. IOSR Journal of Humanities and Social Science, 22(4), 100-107. https://doi.org/10.9790/0837-220406100107

Purwati, N., Zubaidah, S., Corebima, A. D., \& Mahanal, S. (2018). Increasing Islamic junior high school students learning outcomes through integration of science learning and Islamic values. International Journal of Instruction, 11(4), 841-854. https://doi.org/10.12973/iji.2018.11453a

Rahmi, Y. (2019). Metode muraja'ah dalam menghafal Al-Qur`an di Pondok Pesantren Al-Mubarok Tahtul Yaman Kota Jambi. Innovatio: Journal for Religious-Innovation Studies, 19(1), 65-76. https://doi.org/10.30631/innovatio.v19i1.78

Rikardo, R. (2020). Pembelajaran tahfidz Al-Qur'an di Pondok Pesantren Tahfidz Nurul Qur'an Pondok Kelapa Kabupaten Bengkulu Tengah. An-Nizom, 5(1), 33-37.

Rohman, A. (2016). Dimensi-dimensi psikologis tahfidz Al-Qur'an pada anak-anak (Studi tentang tahfidz Al-Qur'an anak-anak di Pesantren 
Yanbu' al-Qur'an Kudus Jateng). Jurnal Intelegensia, 4(2), 78-112.

Sistupani. (2017). Metode tahfidz Al-Qur'an pada pendidikan anak usia dini. Perspektive, 10(1), 1-16.

Supian, Vahlepi, S., \& Sholiha, M. (2019). Strategi pemotivasian dalam pembelajaran tahfizh al-Qur'an. Tarbawy: Indonesian Journal of Islamic Education, 6(2), 176-186. https://doi.org/10.17509/t.v6i2.19679

Thorburn, M., \& Stolz, S. A. (2020). Understanding experience better in educational contexts: The phenomenology of embodied subjectivity. Cambridge Journal of Education, 50(1), 95-105. https://doi.org/10.1080/0305764X.2019.1632798

Wahyuni, A., \& Syahid, A. (2019). Tren program tahfidz Al-Qur'an sebagai metode pendidikan anak. Elementary: Jurnal Ilmiah Pendidikan Dasar, 5(1), 87-96. https://doi.org/10.32332/elementary.v5i1.1389

Yuli, N. G., Haningsih, S., \& Adikrishna, R. (2011). The common room design of Islamic boarding school: A preliminary research in Yogyakarta Islamic boarding school. International Jornal of Engineering \& Technology, 11(4), 156-163. 